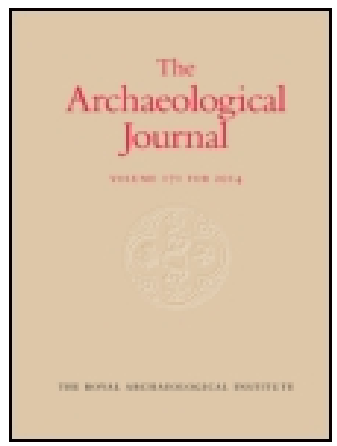

Archaeological Journal

\title{
Anglo-Norman Ornament Compared with Designs in Anglo-Saxon MSS
}

\section{J. Park Harrison M.A.}

To cite this article: J. Park Harrison M.A. (1890) Anglo-Norman Ornament Compared with Designs in Anglo-Saxon MSS, Archaeological Journal, 47:1, 143-153, DOI: 10.1080/00665983.1890.10852418

To link to this article: http://dx.doi.org/10.1080/00665983.1890.10852418

曲 Published online: 15 Jul 2014.

Submit your article to this journal $₫$

Џll Article views: 1

Q View related articles $๘$ 


\section{ANGLO-NORMAN ORNAMENT COMPARED WITH DESIGNS IN ANGLO-SAXON MSS.}

BY J. PARK HARRISON, M.A.

Forty-six years ago Mr. Thomas Wright drew attention to the importance attaching to the architectural details in illuminated Saxon manuscripts; first, as shewing that squared stone was in use in England long before the Norman Conquest, and, next, because numerous details in pre-Norman MSS. so closely resembled distinctive features in existing Churches, that there could be little doubt that they were either of contemporary date, or copied from earlier work that was so. He more particularly alluded to the evidence that the miniatures afforded regarding the style now admitted to be Saxon; but whilst referring to Churches like Deerhurst and Sompting as examples of the better type of pre-Norman buildings, Mr. Wright expressed a strong opinion that much remained to be learnt from more extended research. ${ }^{\mathrm{T}}$

Following, though tardily, this suggestion, a close examination has now been made of all the architectural features and ornaments in the three illuminated MSS. referred to by Mr. Wright, viz: Athelwold's Benedictional, EElfric's Pentateuch, and Cæamon's Paraphrase, besides others of about the same date and English origin, in the British Museum and Bodleian Libraries, and the admirable reproductions of Saxon miniatures and details in MSS. less accessible, in Professor Westwood's "Facsimiles."

Before stating results, it will be well to repeat what was said on the subject of pre-Norman Churches in England in a note communicated to the Institute in

\footnotetext{
1 Journal, British Archæological Association, Vol. I, p. 1.
} 
1883, viz: that in addition to the style now accepted as Anglo-Saxon, which appears to have been derived from wooden structures, there was another, a development perhaps of an earlier one which Professor Freeman some time back proposed should be called English Romanesque. It is this style that is principally illustrated in the illuminated MSS. of the tenth and earlier years of the eleventh century, to which, with one or two exceptions, search has been confined.

The more important churches founded by Kings of England and heads of the great Monastic orders, which were probably erected in the latter style, would have been the first to be rebuilt on a larger scale after the Conquest. A careful search, however, has in more than one instance resulted in the discovery of earlier work in buildings even of this description.

The indentification of such work in Anglo-Norman buildings may prove to be a less difficult task than might at first be supposed, seeing that the style of architecture that existed in Normandy at the time of the Conquest, as ascertained by MM. Bouet and De Caumont, of Caen, in concert with Mr. J. H. Parker, was severely plain. Its Romanesque capitals were in fact the only ornament. ${ }^{x}$

M. Bouet, in his excellent work on the architecture of St. Stephen's Church, mentions that the "chapiteau cubique," or cushion capital, ${ }^{2}$ in its various forms, appeared suddenly in Normandy, as if introduced from abroad, and presumably from England, in the twelfth century, at about the same period as the embattled fret and triple arrangement of clear-story arches. In the thirteenth century, also, the rare capital with inverted volutes appears in the apse of St. Stephen's Church, and M. Bouet

1 The following extract is from a paper by Mr. Parker on this subject. "The great Abbey Churches at Caen had long been considered the starting point for the history of architecture in England, and the connecting link between the architectures, and at the same time it had been taken for granted that these Churches, as they now stand, were fair examples of the style of building in use in Normandy at the time of the Conquest. A careful examination, however, shewed that this was almost entirely a delusion, which had greatly misled the generality of English historians and amateurs. When he came to examine these churches in detail, with the careful observation required by the system of Professor Willis, he found that in the Church of St. Stephen there was such a difference of construction in different parts, is to mark the work of three distinct periods." Proceedings of the Oxford Architectural and Historical Society, vol. 1, New Series.

2 See p. 49 , Analyse Architecturale de L'Abbaye de Saint-Etienne de Caen. Par G. Bouet, in the library of the Institute, 
states that it was previously used in Sherborne Chapel, Durham, by Bishop Pudsey, in the twelfth century. Now this capital occurs in the Saxon church of Merton, Lincolnshire, and in three distinct illuminated MSS. of tenth century date. [Nos. ii, xii, and xiii in the list].

The architectural details in the MSS. above referred to are as follows :-

I. Psalter. B.M. 603, 11th century.

Arcades.

Square turrets.

Battlements.

Tall narrow doorways.

Ashlar.

Church with clear-story.

Twisted column.

Cushion capitals.

Picture of a mason making use of a pointed chisel.

[Note. Most of the miniatures in this MS, are copies of those in the Utrecht Psalter, which was of much earlier date.]

II. Gospels in Latin. Bod. Laud, 102, 9th century.

Arcades of four arches over calendars.

Foliated capitals.

Ornamented pillars.

Inverted volutes.

III. Psalter of King Athelstan. B.M. end of 9th century.

Two round arches, indicating a building with an aisle.

Mouldings, or chamfers.(?)

Cushion-shaped capitals.

Sloping bases.

Holy cradle, in form of a church, with an arcade in lower stage, three round windows and clear-story. [Pl. III, fig 5.]

IV. Latin Psalter. Salisbury Cathedral. 9th or 10th century.

Round arches.

Foliated capitals.

Lines indicating mouldings.

Shafts at corners of piers (?)

VOI. XIVII 
V. Æthelwold's Benedictional. ${ }^{1}$ Eaton Hall, c. 1000.

Intersecting arches.

Double arches under an embracing arch.

Square turrets.

Piers with panels, or corner shafts. (?)

Twisted pillars (on a throne).

Foliated capitals.

Bomanesque bases.

Intertwining stalks.

Ashlar, in courses of different heights.

Acanthus foliage.

Holy cradle, in form of a church, with aisles and clear-story.

Balustered shafts.

VI. AElfric's Anglo-Saxon Pentateuch.

B.M. Claudius B. IV, c. 1000 .

High arches.

Apse.

Sub-arches, springing from attached shafts.

Square turrets. [Pl. III, fig 4.]

Tall narrow doorways.

Ashlar, in courses of unequal height.

Battlements.

Small arcades.

Bell-shaped capitals.

Cushion capitals.

Foliated capital. [Pl. II. fig 7.]

Capitals with pointed leaves. Pl. II. fig. 10.]

Capitals with volutes.

Sloping bases.

Doorway with tympanum.

Twining stalks and leaves.

Acanthus leaves.

Star-shaped diaper, (on a throne.)

Zigzag border. [Pl. III, fig 12.]

Cable moulding. [Pl. III, fig 10.]

VII. Cædmon's Paraphrase. ${ }^{2}$ Bod. Junius, 2, c. 1000.

Diaper work. [Pl III, fig 1.]

Arches springing from half capitals.

Triple clear-story arches.

1 Reproduced in Arohæologia, Vol, xxiv.

See Archæologia, Vol, sxiv. 
Turrets, with two-light windows.

Tall narrow doorways.

Small arcades.

Piers with panels (?), or corner shafts. (?)

Ashlar, in unequal courses.

Rounded, or cushion capitals.

Capitals with volutes.

Capitals with interlacing stalks.

Rounded bases.

Acanthus foliage.

Battlements.

VIII. Latin Psalter. Bod. Junius, 27, 10th century.

Acanthus foliage.

[Initial letters only.]

Stalks issuing from tubes or pipes. [Pl. II, fig 2.]

Eagles' heads in involved foliage.

IX. Prudentius. Bod. early 11th century.

Acanthus foliage.

X. Dunstan. B.M. Claudius, A, 3, 10th century.

Tall narrow doorways.

Two square turrets.

Shafts ornamented with chevrons.

Label decorated with minute arches. [Pl. II, fig 1.]

Twining stalks and leaves.

Female head, with leaf head-dress. [Pl, II, fig 1.] Acanthus leaves.

XI. Litany.' Bod. 775, late 10th century.

[Two initial letters only.]

Interlacing bands. [Pl. II, fig. 4.]

Twining foliage.

XII. Gospels. B.M., Cal. vii,, early 11 th century.

Inverted volutes.

XIII. Psalter. B.M. Tiberius, C. VI, early 11 th century. [Ideal Holy Sepulchre. ${ }^{2}$ ]

Arcades of small arches.

Circular windows.

Twisted pillar with foliated capitals.

Steps ornamented with zigzags. [Pl. III, fig 11.]

1 This Litany contains a prayer for King Ethelred and the English Army.
2 Reproduced in Westwood's "Fac. similes." 
Line of pellets.

Well proportioned round-headed windows.

Bands of bead ornament. [Pl. III, fig 9.]

Inverted volutes. [Plate II, fig 9.]

XIV. Hymnal. B.M. Caligula XV, 11th century. Arcade of small arches.

Square turrets.

Church with aisles and clear-story.

Apse at end of an aisle (?)

Tall portals.

Moulded arches.

Battlements.

XV. Psalter. B.M. Har. 2904. Acanthus leaves.

XVI. Missal of Bishop Leofric. Bod. c. 1000. Acanthus foliage.

Most of the features in this list occur in the Church of the Holy Trinity, St. Mary and all Saints, ${ }^{1}$ now the Cathedral of Christ in Oxford, namely: (1) square turrets; (2) intersecting arches; (3) couplets under embracing arches : (4) clear-story windows flanked by small arches; (5) arcades; (6) sub-arches springing from halfcapitals inserted in main columns; (7) cylindrical pillars of unusual height; (8) arches with roll mouldings ; (9) doorways and windows with side shafts; (10) circular window; (11) tall narrow doorways; (12) cushion capitals; (13) capitals ornamented with intertwining stalks: in some cases issuing from pipes; (13) capitals formed of three pointed leaves; (14) capitals ornamented with acanthus leaves ; (15) scolloped capitals ; (16) capitals with inverted volutes; (17) cornices or imposts ornamented with fivepetalled leaves ; (18) bead ornament; (19) ashlar in unequal courses ; (20) leaf head-dress; (21) sloping bases; (22) slightly projecting rounded bases ; (23) bases formed of two rolls with a straight line between them (in the clear-stories); (24) foundations of apses. Besides fragments of string courses ornamented with zigzags, \&c., found built into walling of post-Norman date.

1 This was the ancient Dedication of St. Frideswide's Church, and it was adopted by Wolsey for his intended College; with the addition of the name of St. Frideswide, see engraving of Seal in Dugdale, 
Though the features enumerated correspond with miniatures and ornamental details in pre-Norman MSS. this does not, of course, in itself, show that any of the work at Christ Church Cathedral is pre-Norman; for earlier Saxon work may have been copied. Close examination, however, has led to the discovery of a "break of joint" between the choir and the transepts, and a difference of size in the capitals at the junction, which prove that there was no continuity in the work such as has been supposed; and that the choir is much older than the rest of the Church, though greatly altered in appearance, in the twelfth century, by the addition of the new presbytery, the chancel-arch and tower shafts, and the reconstruction of the tower arches, which appear once to have sprung from imposts ${ }^{1}$; and still more by the introduction of vaulting, and vaulting shafts in the aisles, not contemplated in the original plan.

This, however, is not all. The arrangement of arches springing from half capitals, inserted in main pillars, is clearly represented in a miniature in Cædmon; (see plate III, fig 2), and is not found in any other church except Oxford Cathedral. ${ }^{2}$ A reason might perhaps be given for this unusual plan, if, as history seems to imply, Eithelred's Church, which was added on to an older building with low walls was never taken down.

That several of the choir capitals, which also correspond with patterns in Cædmon and other pre-Norman MSS., are older than any in the nave or transepts, is evident from their weathered condition; due either to exposure for some time to the open air, perhaps from decay of the roof, indicated by the non-acceptance of the Church on account of its state of repair, when offered by the Conqueror to the Prior of Abingdon; or, from the length of time the capitals have been subjected to the ordinary softening effects of the atmosphere.

Ten capitals in different parts of the Cathedral have inverted volutes. The earliest perhaps are in the north arcade inside the Tower and the south triforium of the choir; and then the one in the south east corner of the

\footnotetext{
${ }^{1}$ This seems evident from the mutilation of the rows of leaves occasioned by the insertion of the twelfth century capitals.
}

${ }^{2}$ At Romsey there are sub-arches which spring from attached shafts, not half caps. At Jedburgh sub-arches spring from corbels. 
south transept. [Plate I, fig 3.] The latest is in the nave on the south side.

An early example exists at the west end of the arcade in the north aisle of the nave of Peterborough Cathedral, where there is other work, that, it can scarcely be doubted, is copied from features in an earlier church.

The twining stalks in four of the choir capitals at Oxford, with pipes, out of which the stalks issue, correspond very closely with designs in late 10th century MSS. [Plate II, fig 2.]

Also in two other capitals the arrangement of acanthus leaves is very similar to that in borders round miniatures in some of the beautiful Winchester MSS. of tenth century date, when, as Prof. Westwood informs us, there was a remarkable revival of such foliage. [Plate II, figs 5 and 6.]

It has already been stated in a former paper ${ }^{1}$ that portions of the walls and foundations of apses of the ancient church of the Holy Trinity, which was renovated and enlarged by Ethelred II in the beginning of the eleventh century, are still in existence. The jambs of a doorway belonging to the original church go down $2 \mathrm{ft} .8 \mathrm{in}$. below the pavement of the north aisle of the choir in which it is situated. The doorway would clearly have been tall and narrow, and its arch is very straight sided.

There are other features found in the illuminated MSS. and, also, at Christ Church, which it is important to note, viz: square and round turrets: [Plate III, figs. 4, $6,7$,$] and clear-story triplets.$

A mistake regarding the date of the choir of the Cathedral seems to have arisen from the circumstance that, when the remains of St. Frideswide were placed in a feretrum in the north aisle in 1189, the Archbishop of Canterbury took part in the ceremonies. From this it has been concluded that the church was consecrated on the same occasion. It was not, however, the practice to postpone consecration until the completion of a church. The translation of St. Frideswide's remains in all probability took place when the alterations in the north choir aisle were finished, which would have been about 1189 . There is no documentary eviI "Recent Discoveries in Orford Cathedral." Arch. Jour., 1888. 
dence pointing to any consecration but that of Ethelred's church ; and, as Dr. Ingram pointed out, there is not a tittle of evidence to show that it was ever pulled down: however much it may have been altered. ${ }^{1}$

As regards other Anglo-Norman Cathedrals, though Britton's view, that the Normans when rebuilding English churches adhered both from policy and choice to the severe style of architecture they brought with them, may be accepted as generally correct, there are instances of the adoption of ornamental features from Anglian churches soon after the Conquest, e.g., at Lincoln and Winchester. At Lincoln Remigius built the three great portals at the west end of the Cathedral in identically the same style as that of the Conqueror's Church at Caen, at that date; that is to say, with square soffites to the arches, and debased Romano-Corinthian capitals. In the narrow apsided recesses, however, on either side (if, as seems to have been the case, they were erected at the same time), though the two lower orders are without mouldings, the outer rims are ornamented with a roll and decorated label, both of which appear to have been copied from features in the old Cathedral at Stow. The same pattern appears on an arch in the picture of Dunstan (so called), in the Cottonian MS., Claudius A., 3 (No. $x$. in the list). See Plate II, fig 1. It occurs also on a string course round the walls at Stow which were rebuilt at the end of the eleventh century. ${ }^{2}$

The second instance of early adoption of Saxon ornament is the use of the cubic or cushion capital by Walkelyn at Winchester. This form of capital, as has already been mentioned, was not known, or at any rate was not used, at Caen until the twelfth century. ${ }^{3}$

\footnotetext{
1 " There is no proof or record to shew that Ethelred's work was destroyed; * * * Yet this was, without doubt, a work of considerable magnitude, for in the Royal Charter, which is still extant, the Church is said to have been renovated by the help of God, through the exertions not only of the king, but of his people, * * * So great was the satisfaction which the king derived from the restoration, that in the half modernised orthography of the Langbourn Manuscript, he calls it "myne owne

mynster in oxen forde." Ingram : Memorials of Oxford. vol. 1.

${ }^{2}$ A careful sketch of the ornamentation on the deep imposts of the south doorway of the Saxon Church of Barholm, near Stow, which has been sent to me, shows a double row of the same small round arches, and under them a line of zigzags, and a curious pattern resembling a row of fish conventionally treated. There is a fragment similarly ornamented in the gallery over the vestry at Christ Church.

${ }^{3}$ See p. 1, ante.
} 
If the size of Oxford Cathedral should be pointed to as more considerable than that of other pre-Norman churches, it should not be forgotten that Ethelred II was brother-in-law of Duke Richard of Normandy, who, according to the annalist of Fontenelle Abbey, was so distinguished for his art-knowledge that bishops and monks, both Greek and Armenian, journeyed from the east to visit him. He was also the founder of Bernay Abbey and the Church of St. Michel's Mount, in both of which there are capitals like some in Oxford Cathedral, where, according to Sir G. G. Scott, there is clearly evidence of eastern influence.

In conclusion ; in his last work on ' Gothic architecture,' Mr. Parker wrote as follows:

"The Saxons appear to have been more advanced in the fine arts, such as sculpture, than the Normans; but their churches were on comparatively a small scale, and were generally swept away by the Normans, as not worth preserving."

And again, "recent observations seem to shew that the Saxons were more advanced then the Normans at the time of the Conquest; their work was more highly finished, had more ornament, and they ùsed fine jointed masonry, while the Normans used wide jointed."

Further examination of the masonry and ornamental features of the Cathedral will be made as opportunity offers.

\section{DESCRIPTION OF PLATES.}

I.

Fig 1. Capital, north side of choir, Oxford Cathedral; shewing stalks issuing from pipes.

2. Capital ornamented with acanthus leaves.

3. Quarter-capitals at west end of south aisle of choir ; to illustrate break of joint, and inverted leaves.

II.

Fig 1. Part of border and apse of church; from M.S. Dunstan in B. M. shewing head dress formed of foliage, and an ornamented arch. No. $x$ in list.

2. Initial letter from Vossianus. Bod. Stalks issuing from pipes viii. 


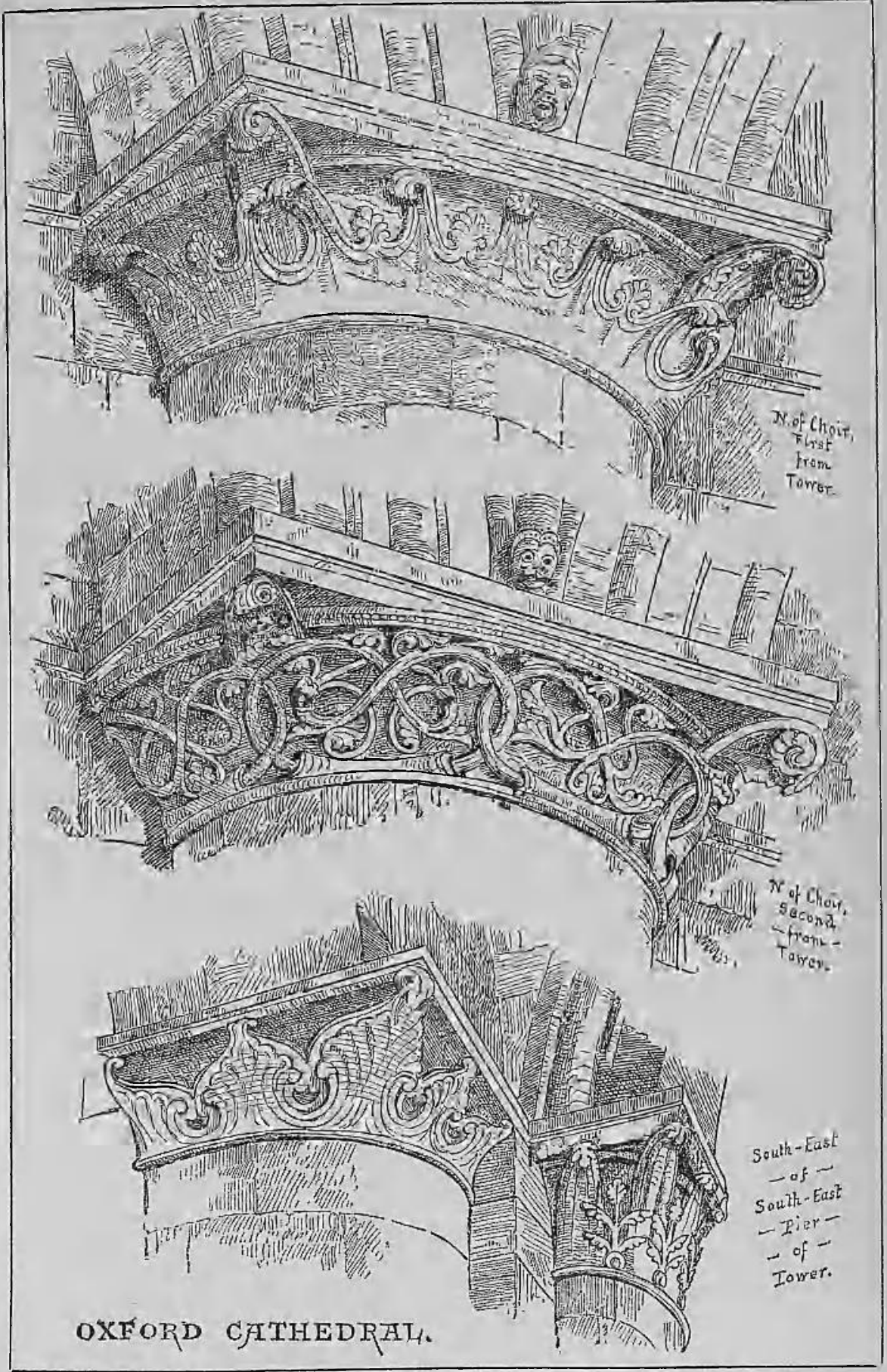



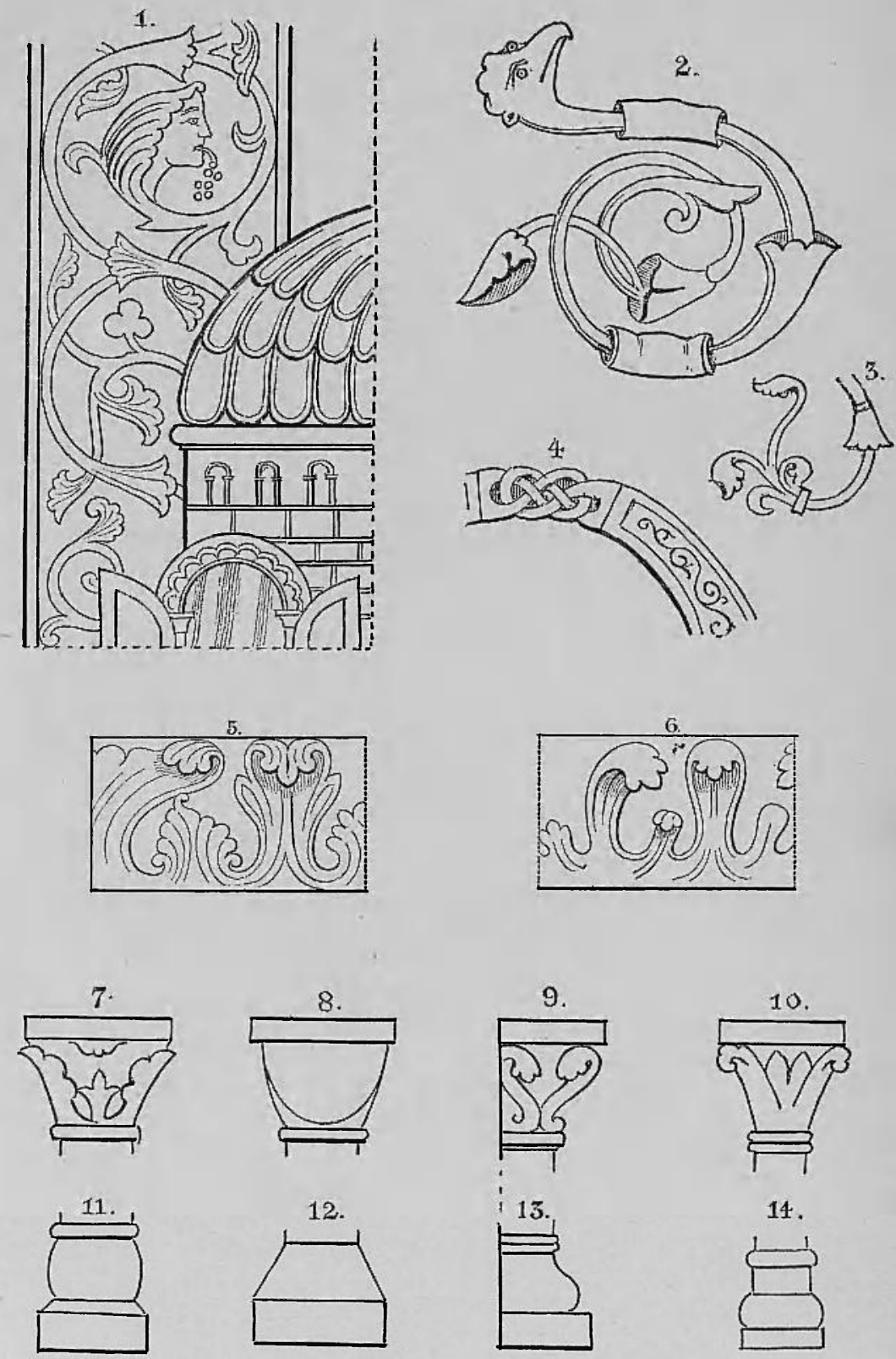

13.

14.
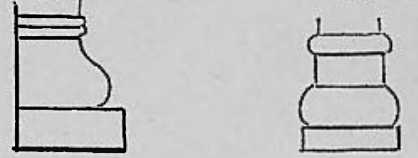

PrE-NORMAN ORPNAMENT: 
PLATE III *
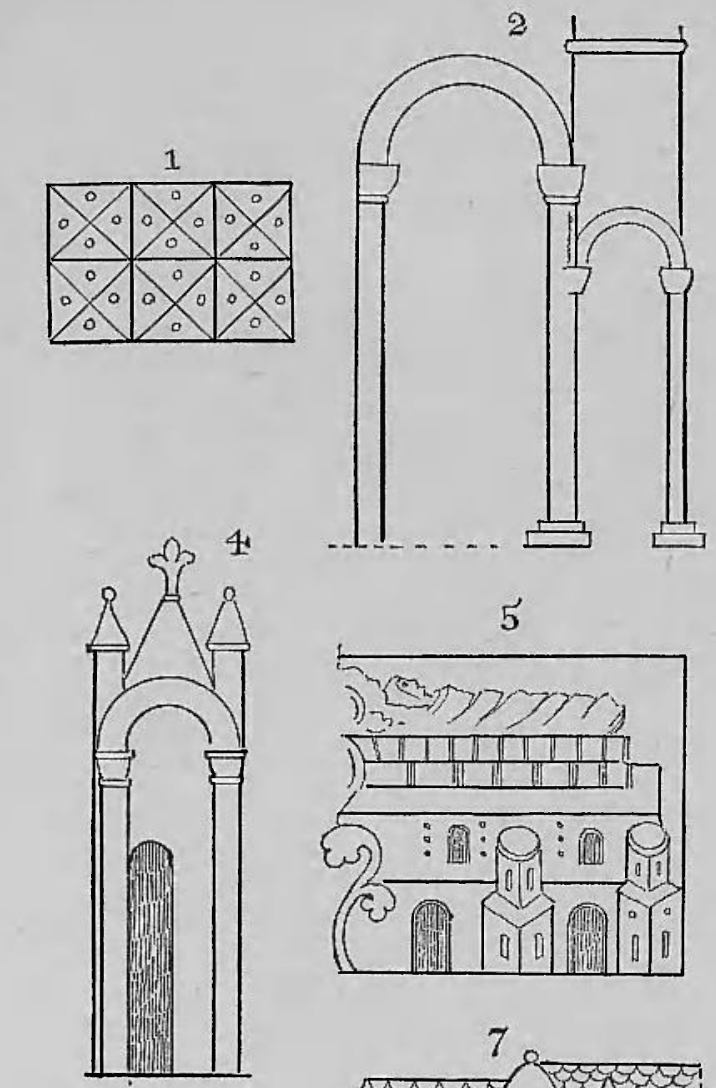

3.
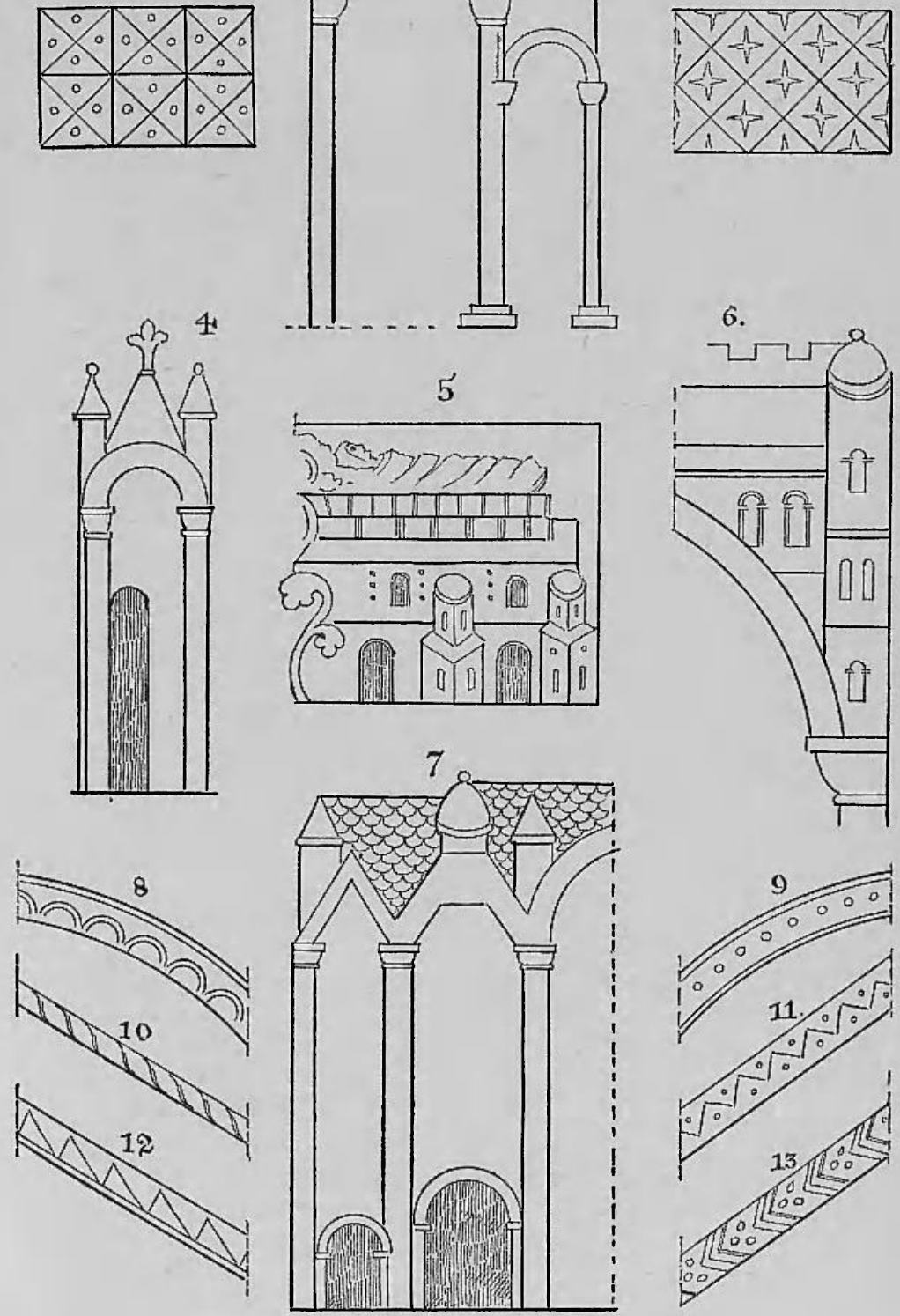

PRE-NORMAN ORNAMENT. 
3. Part of Border. $\mathbf{x}$.

4. Part of illuminated letter. xi.

5. Border of acanthus leaves. $x \nabla$.

6. Ditto ditto ditto. $x v i$.

7. Foliated capital. vi.

8. Cushion do. vi.

9. Capital with inverted volutes. $\mathbf{x}$.

10-13. Pre-Norman bases.

14. Base with two round mouldings. xvii.

Fig 1. Diaper No. vii.

III.

2. Arch springing from half-capital. vii.

3. Diaper. vi.

4. Square turrets, and tall doorway. vi.

5. Sacred cradle in form of church. vi.

6. Part of church with round turret. xii.

7. Section through church. vi.

8. Ornament on arch. $x$.

9. Ditto. $\mathrm{x}$.

10. Cable ornament. vi.

11. Zigzag pattern. xiii.

12. Saw-tooth ornament. vi.

13. Chevron ditto. 